Alma Mater Studiorum - Università di Bologna DEPARTMENT OF ECONOMICS

\title{
Job Insecurity and Financial Distress
}

Caterina Giannetti

Marianna Madia

Luigi Moretti

Quaderni - Working Paper DSE N॰887

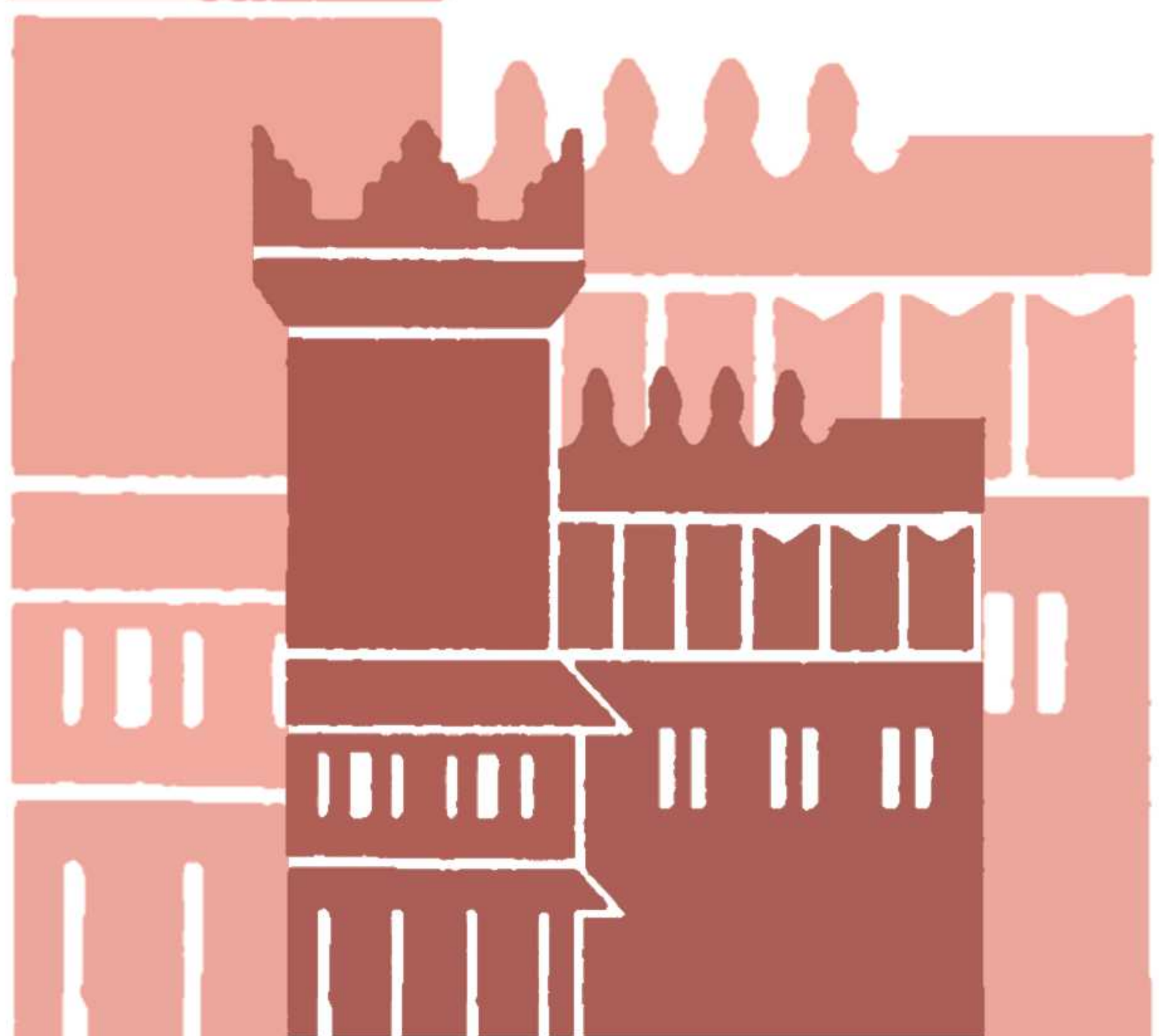




\title{
Job Insecurity and Financial Distress
}

\author{
Caterina Giannetti ${ }^{1}$ Marianna Madia ${ }^{2}$ Luigi Moretti ${ }^{3}$
}

12th June 2013

\begin{abstract}
This paper investigates the effects of different job categories on households' likelihood of experiencing financial distress. Given imperfect financial markets and the absence of unemployment subsidies, households with less secure jobs are likely to experience drops in income more frequently than households with well-protected jobs. Households' abilities to deal with financial decisions (i.e. financial literacy) can mitigate these problems. Our results suggest that greater job insecurity increases the probability of being in financial distress similarly than other working statuses (e.g. unemployment), and in some cases even more (i.e. part-time workers). However, a high level of financial literacy can counterbalance this effect, especially for atypical workers.
\end{abstract}

Keywords: Personal Finance, Debt, Financial Distress, Job Insecurity

JEL Classification: C23; C25; D14

\footnotetext{
${ }^{1}$ Corresponding author. University of Bologna. Department of Economics. Email: caterina.giannetti@unibo.it

${ }^{2}$ Agenzia di Ricerche e Legislazione (AREL). Email: m.madia@arel.it

${ }^{3}$ University of Padua. Department of Economics. Email: luigi.moretti@unipd.it
}

This research has benefited from discussions with a number of people. We would like to thank Fabrizio Coricelli, Vasso Ioannidou, Paola Valbonesi, who provided valuable feedback. We would also like to thank participants of the internal seminar at Royal Holloway, University of London, University of Groningen, University of Luiss Guido Carli, Cattolica University of Milan, and Baetschmann Gregori for his programs. 


\section{Introduction}

Labor regulations that govern temporary contracts have been continuously reshaped and eased during the last 25 years in Europe, and have been accompanied by the spread of job insecurity. The most significant recent relaxation of job protections occurred mainly in countries that had the strictest employment protections in the early 1990s, such as Italy or Spain (OECD (1994a), Sala et al. (2012)). Although there has been convergence in employment protection regulations among European Union member states, the provisions in case of job loss still vary widely across countries. For example, in Italy the funds allocated to unemployment benefit programmes in 2005 are 0.5 per cent of GDP, as against 1.6 per cent in the EU-27. Italy also remains one of the few European countries still lacking an income support programme for persons excluded from the labour market (Bank of Italy (2008)).

In this regard, it is important to investigate the interactions between labour market policies and financial market imperfections, as both financial markets and redistribution policies play a role in insuring individuals against "bad luck" (i.e. the loss of a job, see for example Pagano and Volpin (2008) and Gatti et al. (2012)). Access to financial instruments, for example, by allowing risk-averse workers to prolong the search for a new job, may allow them to seek out those jobs where they will be most productive (see Giannetti (2011)). On the other hand, a lack of access to insurance and other financial instruments implies that workers have to rely on government redistribution in order to smooth their consumption over time.

Motivated by such issues, in this paper we focus particularly on the relationship between income uncertainty and financial distress. Specifically, the main contribution of our work is to distinguish the effects of different job categories on the probabilities of experiencing troubles in keeping up with payments. Households with less secure jobs are likely to experience income drops more frequently than households with stable and well-protected jobs, as temporary workers are subject to a higher probability of unemployment and earn lower wages (see, for example, Picchio (2006)). Potentially, these households may also experience income drops more severe than households who can rely on unemployment benefits (Jappelli and Pistaferri (2010)). Therefore, especially in the absence of unemployment benefits, these households will have more volatile income (Cappellari and Leonardi (2013)), and will find it more difficult to 
smooth their consumption over time (Benito (2006), Jappelli and Pistaferri (2009), Browning and Crossley (2009)). On the top of that, households with unstable income flows will lack easy access to credit as banks consider them to be riskier borrowers. That is, income uncertainty is expected to exert an effect on both the probability of being faced with credit constraints and the probability of experiencing financial distress. Differently from other papers, we can rely on direct indicators of credit constraints.

Recent contributions in the literature have also highlighted the importance of behavioural characteristics and individual financial capability on financial distress (see McCarthy (2011), Lusardi and Mitchell (2007), Lusardi and Tufano (2009)) as well as the role of risk attitudes in choosing among types of occupation (see Cramer et al. (2002), Bonin et al. (2007)). Thus, depending on households' characteristics (e.g. risk aversion, time preferences, wealth endowment) and their level of financial literacy in making financial decisions, households will differ in their ability to smooth their income over time. In this regard, the dataset we use in our empirical analysis provides information on the level of financial literacy and risk aversion.

Our research questions can thus be summarized as follows: How does job insecurity translate into financial distress? Can access to credit and financial literacy mitigate financial distress? Our results suggest that heads of households with insecure jobs are more likely to experience financial distress. This probability is similar to that of unemployed heads of households, and even higher for heads of households who are employed on a part-time basis. However, higher levels of financial literacy counterbalance the observed negative effects, especially for atypical workers. These results also appear robust in our panel specification, which controls for unobserved head of household's characteristics, for job insecurity measured at family level, as well as for endogeneity problem.

The remainder of the paper is structured as follows: Section 2 reviews the literature on the determinants of financial distress, Section 3 introduces the data used in the current study, while Section 4 covers the econometric techniques used and Section 5 presents estimation results. We will rely on a cross-sectional specification which will support our results with a panel specification for a smaller subset of households. Section 6 presents some robustness analyses of our results to endogeneity problem, model specification and behavioural characteristics. Finally, 
Section 7 summarizes and concludes our argument.

\section{LITERATURE REVIEW}

In the wake of the financial crisis, there is a vast and growing literature, which examines the causes of household financial distress. The definition of financial distress varies across different studies - mostly depending on the dataset at hand - and may range from being "unable to have a holiday" to a more general inability to "make ends meet". In general, the characteristics investigated as possible causes of financial distress include age, sex and marital status, family structure and composition, source and level of household income, debt repayment of various type. For example, Fricke et al. (2007) use the German Socio-Economic Panel (SOEP) and find that age, education and living in partnership significantly reduce debt-related financial problems whereas unemployment has a significant positive effect. Betti et al. (2007) find that over-indebtedness is more frequent among young high-income individuals and lone parents. Brown and Taylor (2008) use the British Household Panel Survey and find that the sources of income are a potential source of financial distress: households with a retired head are more likely to report housing finance difficulties than employees. They also find that previous experience of financial distress is positively associated with the current financial position of the household. Worthington (2005) use the Household Expenditure Survey on Australian Households and provides evidence that financial distress is very much a function of the demographic and socioeconomic characteristics of households (e.g. households on government benefits) and, to a lesser extent, debt portfolios.

Recently, several scholars have highlighted the crucial role of financial literacy on household financial outcomes. With regard to financial distress, McCarthy (2011) looks at the effect, among other factors, of financial literacy on the ability of British and Irish households to manage their income. She finds that financially literate individuals are less likely than financially illiterate individuals to experience financial distress. Lusardi and Tufano (2009) also find a link between debt literacy and over-indebtedness finding that individuals with lower levels of debt literacy tend to judge their debt as excessive, even after controlling for many demographic factors. Their 
analysis also indicates that about a third of the fees and charges paid by low literacy individuals are related to lack of financial knowledge.

In addition to financial literacy, a number of papers specifically address also the role of behavioural characteristics - such as the capacities for self-control or planning - in affecting the individual ability to stay out of financial troubles. In particular, McCarthy (2011) shows that while demographic and economic variables are important determinants of who gets into financial difficulties, behavioural factors also matter, having a stronger impact than education or financial literacy. Relying on survey of Italian households, Anderloni et al. (2012) find that impulsive individuals are more subject to financial distress. Walker (1996), after controlling for demographics and income variables, also finds that time-preferences, financial management and attitudes towards debt are important predictors of the level of household's financial distress.

By looking at the relationship between job insecurity and household ability to keep up with payments, this paper is also indirectly related to the literature which relates different conditions in the labour markets to household consumption smoothing: for working-age individuals, the most important source of uncertainty is without any doubt labour income. The main testable implication of the life-cycle-permanent-income models is that consumption should respond to unpredictable changes to an extent that depends on the characteristics of the shocks itself (i.e. permanent or transitory). From the empirical literature on this topics, however, it emerges that consumption tends to react above what is implied by the consumption smoothing hypothesis and that consumers do not revise their consumption fully in response to permanent shocks (see Jappelli and Pistaferri (2009) for a review). The main reasons have been identified in liquidity constraints and insurance opportunities. In this regards, the conditions that the individuals simultaneously face in the labour market must play an important role. Bertola and Koeniger (2007), for example, study how workers desire and ability to borrow against future labour income depend on institutional features of both labour and credit markets. They show that labour income instability reduces desired borrowing by individuals who expect their income to grow and make it easier for them to obtain credit. Along this line, Magri (2007) using Italian data tests whether credit market reforms in the '90s might have different impacts according to the differ- 
ent condition faced by the workers in the labour markets. She finds that self-employed workers have benefited the most of the reduction in credit market imperfections, whereas she observes an increase in the average amount of consumer loan only for the young employees with a guaranteed job contract. Benito (2006), using microdata on British households, provides evidence of significant precautionary saving effects associated with unemployment risk. In particular, the effect of unemployment is estimated to be significantly stronger for younger households and those households without non-labour sources of income, which reduce non-durable consumption (i.e. food consumption) and delay the purchase of durables.

To summarize, the literature has investigated several drivers of household financial distress. In addition to demographics characteristics, the level of financial literacy - as well as the behavioural traits - of the head of the household have emerged to play an economically important role. A number of papers have also started to jointly investigate the structure of the financial and labour markets as determinants of consumption smoothing, finding that different imperfections in the credit markets can have a different impact on the household consumption behaviour depending on the conditions the individuals face in the labour market. However, none of these studies has yet disentangled the effect of different types of job insecurity on households' financial distress. This is the aim of our paper and of the following empirical investigation.

\section{DATA DESCRIPTION}

In order to perform our empirical analysis, we will rely on the Italian Survey on Household Income and Wealth (SHIW) after 2006, the year in which broad questions about financial literacy were first introduced. Every two years the Bank of Italy uses the SHIW to collect detailed data on household demographics, consumption, income, and wealth for a representative sample of the Italian population. In 2006 the survey covered 7,768 households and 19,551 family

members; in 2008 the survey covered 7,977 households and 19,907 family members; in 2010 the survey covered 7,951 households and 19,836 family members. Relying on this dataset has several advantages.

First, the survey covers questions on all the aspects of our research interests for at least 
three years, allowing us to perform panel data analyses in addition to cross-sectional analysis. Second, using Italian data is particularly pertinent to our research questions as Italy has recently experienced a great increase in job insecurity due to labor market reforms which introduced new (and less-protected) types of work contracts. ${ }^{1}$ Finally, in Italy only a few workers are granted subsidies, thus potentially making credit constraints even more stringent for a large number of workers (Jappelli and Pistaferri $(2009,2010))$. Using the data from Italian National Statistical Institute (Istat)'s labour force survey and the EU-SILC survey of household incomes, the Bank of Italy has estimated that in addition to the vast area of unreported workers, roughly 1.6 million employees or quasi-employees would not be eligible in 2009 for any benefits in the event of a temporary or permanent layoff (even after the Government's targeted measures). These are payroll employees lacking the seniority or social security contribution requirements and managers and quasi-employees for whom there is no provision for unemployment benefits or wage supplementation. ${ }^{2}$ The amount and duration of benefits also differ according to type of employment contract.

Because we are particularly interested in the effect of job insecurity on financial distress, we will only utilize data pertaining to the heads of households who were in the labor force in either one of the two surveys (i.e. employed, self-employed and unemployed), thus excluding retired persons, homemakers, and individuals leaving of independent means. Table 1 reports descriptive statistics for the selected panel and cross-section sample. It is important to notice that in the following analyses, we will rely on the survey weights provided by the Bank of Italy in order to avoid inaccurate estimates and standard errors (Faiella (2008)). The estimates will therefore refer to the overall population.

\subsection{Measuring financial distress.}

In accordance with the recent literature (see for example McCarthy (2011), Lusardi and Mitchell

\footnotetext{
${ }^{1}$ Key reforms include the 1997 Treu measures (Law 197/1997) and the Biagi reform of 2003 (Law 30/2003), both aimed at improving labor market flexibility. The Treu measures, named after then-Labor Minister Tiziano Treu, were the first legislative measures aimed at increasing flexibility via labor market reform "at the margin," primarily by introducing temporary contracts and providing incentives for part-time work. Another law passed in the same year (Law 469/1997) concerning the privatization and decentralization of job centers abolished the principle of a public monopoly on employment services. The Biagi reform, named after the late Marco Biagi, advisor under the 2001-2006 Berlusconi government, further deregulated the use of atypical work arrangements, such as temporary agency work (staff-leasing) and part-time work, and introduced new forms of atypical work arrangements such as on-call jobs (lavoro intermittente), job sharing and occasional work (lavoro a progetto).

${ }^{2}$ For a detailed description see the Labour Market Section - especially Table 9.2 - in the 2008 Annual Report of the Bank of Italy (2008).
} 
Table 1: SUMMARY STATISTICS

\begin{tabular}{|c|c|c|c|c|c|c|c|c|c|c|}
\hline & \multicolumn{5}{|c|}{ CROSS-SECTIONAL SAMPLE } & \multicolumn{5}{|c|}{ BALANCED SAMPLE } \\
\hline Variable & Mean & Std. Dev. & Min. & Max. & $\mathbf{N}$ & Mean & Std. Dev. & Min. & Max. & $\mathbf{N}$ \\
\hline OSTRUGGLE & 3.847 & 1.287 & 1 & 6 & 3506 & 3.827 & 1.221 & 1 & 6 & 3780 \\
\hline AGE & 46.557 & 9.739 & 18 & 82 & 3506 & 48.633 & 9.174 & 21 & 78 & 3780 \\
\hline SINGLE & 0.182 & 0.386 & 0 & 1 & 3506 & 0.13 & 0.336 & 0 & 1 & 3780 \\
\hline DIVORCED & 0.115 & 0.319 & 0 & 1 & 3506 & 0.108 & 0.31 & 0 & 1 & 3780 \\
\hline WIDOW & 0.032 & 0.175 & 0 & 1 & 3506 & 0.038 & 0.191 & 0 & 1 & 3780 \\
\hline SEX & 1.367 & 0.482 & 1 & 2 & 3506 & 1.281 & 0.45 & 1 & 2 & 3780 \\
\hline EDUCATION & 4.499 & 1.546 & 1 & 8 & 3506 & 4.354 & 1.492 & 1 & 8 & 3780 \\
\hline FAMILY SIZE & 2.9 & 1.308 & 1 & 12 & 3506 & 2.973 & 1.276 & 1 & 12 & 3780 \\
\hline FAMILY INCOME HOLDERS & 1.727 & 0.735 & 1 & 6 & 3506 & 1.753 & 0.743 & 1 & 5 & 3780 \\
\hline HOUSE PROPERTY & 0.645 & 0.479 & 0 & 1 & 3506 & 0.679 & 0.467 & 0 & 1 & 3780 \\
\hline DEBTS & 0.311 & 0.463 & 0 & 1 & 3506 & 0.305 & 0.46 & 0 & 1 & 3780 \\
\hline $\log$ INCOME & 9.163 & 2.262 & 0 & 12.206 & 3492 & 8.779 & 2.971 & 0 & 12.938 & 3776 \\
\hline UNEMPLOYED & 0.08 & 0.272 & 0 & 1 & 3506 & 0.129 & 0.335 & 0 & 1 & 3780 \\
\hline INSECURE & 0.087 & 0.281 & 0 & 1 & 3506 & 0.057 & 0.232 & 0 & 1 & 3780 \\
\hline ATYPICAL & 0.014 & 0.116 & 0 & 1 & 3506 & 0.008 & 0.087 & 0 & 1 & 3780 \\
\hline SELF EMPLOYED & 0.164 & 0.37 & 0 & 1 & 3506 & 0.133 & 0.339 & 0 & 1 & 3780 \\
\hline PERMANENT & 0.656 & 0.475 & 0 & 1 & 3506 & 0.674 & 0.469 & 0 & 1 & 3780 \\
\hline PART TIME & 0.253 & 0.435 & 0 & 1 & 3506 & 0.189 & 0.391 & 0 & 1 & 3780 \\
\hline NUMBER JOB EXPERIENCE & 2.291 & 2.041 & 0 & 44 & 3506 & 2.232 & 1.834 & 0 & 36 & 3780 \\
\hline INSECURE FAMILY & 0.133 & 0.407 & 0 & 4 & 3506 & 0.101 & 0.367 & 0 & 5 & 3780 \\
\hline ATYPICAL FAMILY & 0.021 & 0.149 & 0 & 2 & 3506 & 0.02 & 0.142 & 0 & 2 & 3780 \\
\hline UNEMPLOYED FAMILY & 0.107 & 0.403 & 0 & 5 & 3506 & 0.07 & 0.332 & 0 & 5 & 3780 \\
\hline BANK ACCOUNT SAVINGS & 0.926 & 0.262 & 0 & 1 & 3506 & 0.949 & 0.221 & 0 & 1 & 3780 \\
\hline ASK CREDIT & 0.061 & 0.239 & 0 & 1 & 3506 & 0.058 & 0.234 & 0 & 1 & 3780 \\
\hline FIN CONSTRAINED & 0.017 & 0.13 & 0 & 1 & 3506 & 0.01 & 0.101 & 0 & 1 & 3780 \\
\hline MIN MAX LITERACY & 0.532 & 0.471 & -0.5 & 1 & 3506 & 0.534 & 0.375 & -0.5 & 1 & 3211 \\
\hline RISK AVERSION & 3.164 & 0.804 & 1 & 4 & 3506 & 3.173 & 0.774 & 1 & 4 & 3780 \\
\hline PRECAUTIONARY & 48970.999 & 109411.27 & 0 & 2000000 & 3506 & & & & & \\
\hline
\end{tabular}

(2007)), our study defines financial distress as a situation in which the head of the household reports having difficulties keeping up with payments on the basis of the following question, which is available in the 2006, 2008 and 2010 SHIW surveys:

- Is your household's income sufficient to see you through to the end of the month? with great difficulty | with difficulty | with some difficulty | fairly easily | easily | very easily

Specifically, we coded the answers to this question into a categorical variable "OSTRUGGLES", which ranges from 1 (very easily) to 6 (with great difficulty). In 2010, about 42\% of the sample reported having no difficulties keeping up with their income, 29\% reported having some difficulties, whereas 14\% reported having difficulties and great difficulties. Similar percentages can be observed for our balanced sub-sample. Since this question refers to the financial situation of the entire family, in the following analyses we take care of checking the robustness of our results to the inclusion of other regressors that can be computed at the family level (e.g. job insecurity). 
Table 2: POOLED CORRELATION JOB CHARACTERISTICS

\begin{tabular}{|c|c|c|c|c|c|c|c|c|c|c|}
\hline & UNEMPLOYED & INSECURE & ATYPICAL & SELF EMPLOYED & PERMANENT & PART TIME & $\begin{array}{c}\text { NUMBER } \\
\text { JOB EXPERIENCE }\end{array}$ & $\begin{array}{l}\text { INSECURE } \\
\text { FAMILY }\end{array}$ & $\begin{array}{l}\text { ATYPICAL } \\
\text { FAMILY }\end{array}$ & $\begin{array}{l}\text { UNEMPLOYED } \\
\text { FAMILY }\end{array}$ \\
\hline UNEMPLOYED & 1.000 & & & & & & & & & \\
\hline INSECURE & -0.062 & 1.000 & & & & & & & & \\
\hline ATYPICAL & -0.022 & -0.023 & 1.000 & & & & & & & \\
\hline SELF EMPLOYED & -0.100 & -0.098 & -0.038 & 1.000 & & & & & & \\
\hline PERMANENT & -0.401 & -0.422 & -0.151 & -0.675 & 1.000 & & & & & \\
\hline PART TIME & -0.102 & -0.006 & 0.173 & 0.801 & -0.613 & 1.000 & & & & \\
\hline NUMBER JOB EXPERIENCE & -0.015 & 0.114 & 0.012 & -0.047 & -0.018 & 0.022 & 1.000 & & & \\
\hline INSECURE FAMILY & 0.099 & 0.799 & -0.008 & -0.023 & -0.461 & 0.065 & 0.107 & 1.000 & & \\
\hline ATYPICAL FAMILY & 0.011 & -0.010 & 0.667 & -0.051 & -0.093 & 0.094 & 0.019 & 0.007 & 1.000 & \\
\hline UNEMPLOYED FAMILY & 0.901 & -0.056 & -0.020 & -0.090 & -0.361 & -0.092 & -0.027 & 0.098 & 0.029 & 1.000 \\
\hline
\end{tabular}

\subsection{Measuring job insecurity.}

Our definition of an insecure job is based on the type of contract that governs the main employment relationship for the head of the household at the end of the year (a fixed-term or short-term contract). We construct indicators of job insecurity by defining five - mutually exclusive - job categories. First, we can identify those persons who might work regularly for one or more employers but are not on payroll ("ATYPICAL"). Secondly, we can identify those workers who, despite being on payroll, do not have a stable contract; that is, those who have either fixed-term or temporary jobs ("INSECURE"), and conversely, those who do have a permanent contract ("PERMANENT"). Thirdly, we identify those workers who are mainly self-employed ("SELF-EMPLOYED") or are unemployed at the end of the year ("UNEMPLOYED"). ${ }^{3}$ Among the workers who are on payroll, we can also identify those who answered that they were working on a part-time basis, whereas for those who were self-employed we could identify part-time workers whenever the weekly hours were below 35 hours per week ("PART-TIME"). ${ }^{4}$ Further, we can also control for the total number of activities a worker has performed in his or her entire life ("NUMBER JOb EXPERIENCES"). Since the SHIW explicitly reports the type of contract for every household wage earner, for each head of household, we compute the total number of family members under insecure and atypical contracts during the year ("NUMBER INSECURE FAMILY" and "NUMBER ATYPICAL FAMILY"), or who are unemployed at the end of the year (“NUMBER FAMILY UNEMPLOYED”). These latter group of variables enable us to control for job insecurity at family level.

Table (2) reports correlation among the variables describing the characteristics of the head of

\footnotetext{
${ }^{3}$ We do not consider in this category self-employed workers which are mainly working shareholders as this category is substantially different from the previous job categories.

${ }^{4}$ Part-time jobs are frequently of lesser quality than similar full-time jobs in their terms and conditions of employment: hourly wages, non-wage benefits, social protection coverage and even training and career development opportunities (see, for example, Messenger (2010)).
} 
household's job(s). It is interesting to note that most of the part-time activities undertaken are not permanent, meaning that the part-time dummy is in most cases capturing a less secure kind of job. In particular, working on a part-time basis is positively associated with a self-employed activity, particularly an atypical one. Furthermore, the number of job experiences during an individual's life-time is positively associated with current atypical and insecure jobs, as well as with self-employed activities.

\subsection{Measuring financial constraints.}

The survey also provides information about households that were denied credit or discouraged from borrowing during the year. We used the following questions to determine indicators of financial constraints:

- Did the household contact a bank or financial company in 200_ with a view to obtaining a loan or mortgage? Yes I No

- Was the request granted in full, granted in part or refused? granted in full I granted in part I refused

- During 200_did you or a member of the household consider applying for a mortgage or a loan from a bank or financial company but later change your mind because you thought the request would be refused? Yes I No

In particular, we constructed an indicator "ASK CREDIT", which is a dummy variable equal to one if the respondent had contacted a bank or a financial company to obtain a loan or a mortgage, and - conditional on having looked for credit - two indicators of financial constraints: "FIN CONSTRAINTS 1", which is a dummy variable equal to one if the respondent had either been refused or partially granted a loan or mortgage, and zero otherwise; and "FIN CONSTRAined 2", which is a dummy variable equal to one where "Fin CONSTRAINED 1" is equal to one or the respondent had been discouraged to apply for a loan and mortgage, and zero otherwise. Furthermore, in order to take into account the possibility of having financial access, we constructed a dummy variable equal to one wherever the respondent had a bank or post-office (current or savings) account ("BANK AcCOUNT"). In 2010, less than $2 \%$ of Italian households reported being financially constrained. This percentage is slightly above $7 \%$ when one takes into account the households that were discouraged to apply for a loan. If we consider the balanced sub-sample, we can observe similar percentages. Similarly, in both samples, we 
Table 3: JOB CHARACTERISTICS, DEBTS, AND FINANCIAL CONSTRAINTS

\begin{tabular}{|l|c|c|c|c|c|}
\hline & UNEMPLOYED & INSECURE & ATYPICAL & PERMANENT & SELF EMPLOYED \\
\hline ASK CREDIT & 0.041 & 0.080 & 0.035 & 0.060 & 0.058 \\
\hline FIN CONSTRAINED & 0.012 & 0.042 & 0.036 & 0.007 & 0.012 \\
\hline FIN CONSTRAINED 2 & 0.066 & 0.128 & 0.071 & 0.056 & 0.068 \\
\hline DEBTS & 0.243 & 0.249 & 0.286 & 0.327 & 0.277 \\
\hline for mortgage first house & 0.078 & 0.052 & 0.143 & 0.155 & 0.318 \\
\hline for acquiring goods & 0.109 & 0.150 & 0.107 & 0.190 & 0.171 \\
\hline with friends & 0.072 & 0.089 & 0.071 & 0.028 & 0.024 \\
\hline
\end{tabular}

can observe that more than $90 \%$ of the respondents had access to either a bank or post-account. In Table (3), we report the correlation among the main variables describing the characteristics of the head of household's job(s) and our indicator of financial constraints. From this table, it is interesting to note that insecure works are those more actively looking for credit, and - conditional on asking for credit, they are those more likely to see their requested (totally or partially) rejected.

\subsection{Measuring financial literacy.}

In the year 2006, about half the household heads $(3,992)$ were for the first time given an extra module in addition to the standard SHIW questionnaire, aimed at measuring financial literacy. Subsequently, in the 2008 and 2010 surveys, the financial literacy module was part of the survey for all respondents, including both new tests and a portion of the original 2006 questions. Three out of the six original questions in 2008 were directly comparable across surveys in 2006, whereas three out of the six questions asked in 2010 were directly comparable in 2008. Overall, only two answers were directly comparable across surveys and no significant differences in the percentage of correct answers were found. Therefore, to compare the level of financial literacy across across surveys, and to additionally have a concise indicator of financial literacy that is not affected by total numbers of questions, we construct the following min-max indicator:

\footnotetext{
${ }^{5}$ The precise wording of those three questions is:

1. Imagine you receive this statement from your bank; can you tell me what sum of money is available at the end of May? Amount in Euros I Don't know

2. Imagine leaving $€ 1,000$ in a current account that pays $2 \%$ annual interest and has no charges. Imagine also that inflation is running at $2 \%$. Do you think that if you withdraw the money in a year's time you will be able to buy the same amount of goods as if you spent the $€ 1,000$ today? Yes I No, I will be able to buy less I No, I will be able to buy more I Do not know

3. Which of the following types of mortgage do you think would allow you from the very start to fix the maximum amount and number of installments to be paid before the debt is extinguished? Floating-rate mortgage I Fixed-rate mortgage I Floating-rate mortgage with fixed installments I Do not know
} 
which basically relates the total number of correct answers (the numerator) with total number of possible correct answers (the denominator), while taking into account the total number of posed questions.

\subsection{Households' characteristics.}

Finally, recent contributions in the literature have highlighted the important contribution of behavioral characteristics to individual financial capability and distress (see McCarthy, 2009), as well as the role of risk attitudes in choosing among types of occupation (see Cramer et al. (2002); Bonin et al. (2007)). Because some occupations are riskier than others in terms of risk of injury, fatality, or insufficient earnings, occupational choice is likely to depend on an individual's attitude towards risk. In the survey, it was possible to use the following question to capture risk aversion on the part of the head of the households:

- How would you describe your attitude when you manage your financial investments? Are you someone who looks for very high returns, regardless of a high risk of losing part of your capital I a good return, with reasonable security for your invested capital I a reasonable return, with a good degree of security for your invested capital I low returns, without any risk of losing your capital

Specifically, we constructed a categorical variable ("RISK AVERSION") which is equal to four for individuals who are highly risk averse (i.e. they prefer low return and low risk of losing their capital), to three for individuals who are moderately risk averse (i.e. they prefer reasonable return with a good degree of security), to two for individuals who are moderately risk loving (i.e. they prefer good return with reasonable security for their capital), and to one for individuals who are highly risk loving (i.e. they prefer high returns regardless of the risk of losing part of their capital) ${ }^{6}$

We also collected demographic information, including the household head's sex ("SEX"), his or her level of education ("EDUCATION"), his or her civil status ("SINGLE", "DivORCED",

\footnotetext{
${ }^{6}$ Experiments confirm the behavioral validity of this kind of measure. See for example Dohmen et al. (2011).
} 
Table 4: VARIABLES DESCRIPTION

\begin{tabular}{|c|c|}
\hline Variable & Description \\
\hline OSTRUGGLES & $\begin{array}{l}\text { Categorical variable equals to } 1 \text { for all respondents reporting to very easily managing their income, to } \\
2 \text { if reporting easily managing, to } 3 \text { if reporting fairly easily, to } 4 \text { if reporting some difficulties, to } 5 \text { if } \\
\text { reporting difficulties, and to } 6 \text { if reporting great difficulty. }\end{array}$ \\
\hline AGE & Age of the head of the household. \\
\hline SINGLE & Dummy variable equals to 1 for all respondents reporting to be single, and 0 otherwise. \\
\hline DIVORCED & Dummy variable equals to 1 for all respondents reporting to be divorced, and 0 otherwise. \\
\hline WIDOW & Dummy variable equals to 1 for all respondents reporting to be widow, and 0 otherwise. \\
\hline SEX & Sex of the head of the household. \\
\hline EDUCATION & Categorical variable measuring the level of education of the head of the household. \\
\hline FAMILY SIZE & Household number of components. \\
\hline FAMILY INCOME HOLDERS & Household number of components earning an income. \\
\hline HOUSE PROPERTY & $\begin{array}{l}\text { Dummy variable equals to } 1 \text { for all respondents reporting to be owner of the house the household is } \\
\text { living in, and } 0 \text { otherwise. }\end{array}$ \\
\hline DEBTS & $\begin{array}{l}\text { Dummy variable equals to } 1 \text { for all respondents reporting to have outstanding debts (i.e. mortgage on } \\
\text { the first house, debts from family or friends, and debts for acquiring goods). }\end{array}$ \\
\hline $\log$ INCOME & $\begin{array}{l}\text { Logarithm of the income of the head of household, which takes into account all sources of income (e.g. } \\
\text { benefits if unemployed) }\end{array}$ \\
\hline UNEMPLOYED & Dummy variable equals to 1 for all respondents reporting to be unemployed, and 0 otherwise. \\
\hline PERMANENT & Dummy variable equals to 1 for all respondents reporting to have a permanent job, and 0 otherwise. \\
\hline ATYPICAL & $\begin{array}{l}\text { Dummy variable equals to } 1 \text { for all respondents reporting to be atypical (self-employed) workers in their } \\
\text { main activity, and } 0 \text { otherwise. }\end{array}$ \\
\hline PART TIME & Dummy variable equals to 1 for all respondents reporting to have a part-time job, and 0 otherwise. \\
\hline NUMBER JOB EXPERIENCE & $\begin{array}{l}\text { Numerical variable measuring the total number of job experience the head of the household had in his } \\
\text { life. }\end{array}$ \\
\hline INSECURE FAMILY & Numerical variable measuring the total number of insecure activities in the year in the family. \\
\hline SELF EMPLOYED FAMILY & Numerical variable measuring the total number of self-employed activities in the year in the family. \\
\hline UNEMPLOYED FAMILY & Numerical variable measuring the total number of unemployed individuals in the year in the family. \\
\hline BANK ACCOUNT SAVINGS & $\begin{array}{l}\text { Dummy variable equals to } 1 \text { for all respondents reporting to have either an account either at a bank or } \\
\text { at the post-office, and } 0 \text { otherwise. }\end{array}$ \\
\hline ASK CREDIT & $\begin{array}{l}\text { Dummy variable equals to } 1 \text { for all respondents reporting to have contacted a bank or a financial com- } \\
\text { pany to obtain a loan or mortgage, and } 0 \text { otherwise. }\end{array}$ \\
\hline FIN CONSTRAINED 1 & $\begin{array}{l}\text { Dummy variable equals to } 1 \text { for all respondents reporting to have been refused or partially granted a } \\
\text { loan or a mortgage, and } 0 \text { otherwise. }\end{array}$ \\
\hline FIN CONSTRAINED 2 & $\begin{array}{l}\text { Dummy variable equals to } 1 \text { for all respondents reporting to have been refused, partially granted a loan } \\
\text { or a mortgage, or to have been discouraged to apply for it, and } 0 \text { otherwise. }\end{array}$ \\
\hline MIN MAX LITERACY & $\begin{array}{l}\text { Numerical variable measuring the total number of correct answers on financial issues in relation to the } \\
\text { maximum and minimum number of correct answers. }\end{array}$ \\
\hline RISK AVERSION & Categorical variable measuring the level of risk aversion of the head of the household. \\
\hline
\end{tabular}

"WIDOW" or "MARRIED"), income ("LOG INCOME") and debts ("DEBTS"). In particular, the variable "LOG INCOME" measures all possible sources of income for each respondent in each year, including any possible transfer from private or public entities, whereas the variable "DEBTS" is a dummy equal to one where the respondent reported having either a mortgage or a debt for acquiring goods (e.g. vehicle), or a debts towards family or friends. ${ }^{7}$ We can also include information on the household's property ("HOUSE PROPERTY"), size ("HOUSEHOLD SIZE"), and on the number of persons in the household who are income holders ("FAMILY INCOME HOLDERS").

\section{Table (4) reports the description of the variables used in our empirical investigation.}

\footnotetext{
${ }^{7}$ We checked the robustness of our results, also controlling for each type of debt, separately.
} 


\section{Empirical models}

In accordance with the variables specification discussed in Section 3, we estimated the following probability function for households that experienced financial distress:

$$
\operatorname{Pr}\left(y_{i t}=k\right)=\operatorname{Pr}\left(\tau_{k}<y_{i t}^{*} \leq \tau_{k+1,}\right)=\operatorname{Pr}\left(\tau_{k}<x_{i}^{\prime} \beta+u_{i t} \leq \tau_{k+1,}\right)=\mathrm{F}\left(c_{k+1}-x_{i}^{\prime} \beta\right)-\mathrm{F}\left(c_{k}-x_{i}^{\prime} \beta\right)
$$

where $u$ is logistic distributed with $F(x)=e^{x} / 1+e^{x}$ and

$$
\begin{aligned}
& x_{i}^{\prime} \beta=\alpha \text { INDIVIDUAL CHARACTERISTICS }+\gamma \text { FAMILY CHARACTERISTICS }+\lambda \text { JOB CHARACTERISTICS } \\
& +\delta \text { FINANCIAL LITERACY }+\theta \text { FINANCIAL ACCESS }+\mu i+\varepsilon i t
\end{aligned}
$$

In the ordinal logit specification the dependent variable is "OsTRUGGLES" $\left(y_{i t}\right)$, which considers all the possible range of income difficulties, from "very easy" to "with great difficulties". In other words, we observe an individual in a financial situation $k$ (with $k=1, \ldots ., K$ ) where the financial situation (an unobservable latent variable $y_{i t}^{*}$ ) does not pass specific threshold $\tau$, which is assumed to be strictly increasing $\left(\tau_{k}<\tau_{k+1} \forall k\right)$ and $\tau_{1}=-\infty$ and $\tau_{K+1}=\infty$.

We performed two types of analyses specifically: a cross-sectional ordinal logit analysis for the probability of experiencing financial distress, and a panel ordinal logit analysis, which allows us to control for unobservable individual characteristics ( $\mu_{i}$ above).

In addition to the head of the household's job (e.g. Permanent, Part-time) and demographic characteristics (e.g. AGE, EDUCATION, SEX), we include among our regressors the head of household's financial access (i.e. FIN CONSTRAINTS and BANK ACCOUNT), and level of financial literacy. We also controlled for household characteristics (e.g. HOUSEHOLD SIZE, HOUSE-OWNERSHIP, DEBTS), and for job insecurity measured at family level (e.g. INSECURE FAMILY). In the robustness section - for a smaller number of subjects - we also controlled for behavioral characteristics.

Estimating equation (1) in a panel setting implies accounting for unobserved personality traits $\left(\mu_{i}\right)$ that may be correlated with explanatory variables, while at the same time accommodating the ordinal nature of the dependent variables. In this case, in fact, the standard recoding of the ordinal response into a binary response, by defining for example a threshold above which the value would take the value of one (e.g. individuals with some difficulties, $k \leq 3$ ) - could lead 
one to disregard important variations in the original variable. Although it has been a standard strategy applied in the literature, Baetschmann et al. (2011) have recently shown that it could lead to inconsistent estimates. In particular, they show that all the estimators based on the conditional logit estimator (Chamberlain (1980)) on the recoded variable are largely inconsistent. They also propose a new estimator ("Blow Up and Cluster" - BUC) which recodes the original variable into $k-1$ different dichotomizations using $k-1$ thresholds, duplicates $k-1$ times each observation of the original data ("blowing-up"), and then applies to this new dataset a standard conditional logit estimators with clustered standard errors ("cluster"). In their Monte Carlo analysis Baetschmann et al. (2011) show that this estimator outperforms other traditional estimators where the ordered dependent variable displays extremely low response for some categories with a short time span.

To account for the panel structure of our dataset, we will also estimate a random ordinal logit model with clustered errors (Rabe-Hesketh and Skrondal (2008)). A random structure is to be preferred when the dataset unit heterogeneity (i.e. "between-groups" variability) is as in our case - larger than "within-groups" variability (see Molenberghs and Verbeke (2000)). In particular, the random intercept model treats the individual-specific effect $\left(\mu_{i}\right)$ as a random variable with a normal distribution, and eliminates it by integrating over this distribution.

\section{Results}

\subsection{Cross-sectional results: Ordinal logit}

Table (5) reports results from the ordinal logit specification. We report exponentiated coefficients that can be thought of as the odds ratio $(\operatorname{Pr}(y \leq k) / \operatorname{Pr}(y>k))$ of being in a higher category for a one-unit variable change: odds greater than one suggest a positive effect, whereas a rate lower than one suggests a negative effect. The base job category, on which estimates must be compared, is represented by heads of households with a permanent job ("PERMANENT"). Results for demographic variables and income are in line with the literature. Older individuals in particular are less likely to experience financial struggles, ${ }^{8}$ whereas financial struggles are more

\footnotetext{
${ }^{8}$ The square of age was included in the analyses performed; this was ultimately not significant.
} 
likely for people who have suffered relationship breakdowns, live in bigger families, and who do not own their homes. The level of income has a negative effect (i.e. the odds ration is less than one), meaning that individuals with higher income are less likely to experience financial struggles.

Work type and status also matter for financial distress: individuals with a greater number of insecure jobs will be approximately $7 \%$ (i.e. an odds ratio $\approx 1.07$ ) more likely to experience financial distress than individuals with a permanent job (the base category). This effect is economically and statistically similar to the one for unemployed individuals, which is equal to $9 \%$. However, it is important to note, that for individuals with insecure jobs there might be an additional effect of $5 \%$ which arises from having a part-time job (see column $b$ ) and an additional $1 \%$ when controlling for the number of job experiences (see again column $b$ ). For atypical workers the results are instead not statistically significant, although even in this case we cannot exclude the possibility for atypical workers of also working on part-time basis. It is also interesting to note that in our sample, respondents with insecure jobs tend to have more debts resulting from acquiring goods (for example, vehicles) than unemployed individuals. This in turn led to a higher probability of being unable to repay such debts, should the contracts not be extended. ${ }^{9}$ Being self-employed seems to significantly reduce the probability of having financial troubles.

As expected, financial access and constraints also seem to affect the probability of experiencing financial struggles. In particular, a respondent with access to a bank account is about $11 \%$ more likely to have an income which allows him or her to see through the end of the month compared to a respondent without any account, whereas a respondent who reported being financially constrained will be about $15 \%$ more likely to be unable to successfully manage their income. Results are also robust when considering respondents that were discouraged from borrowing (i.e. "FIN CONSTRAINED 2").

Table (5) reports results for the specifications also controlling for the level of financial literacy, from column $c$ to $g$, and risk aversion, from column $d$ to $g$. It is important to notice first that in no case is there a drastic change in the coefficients with respect to the baseline specification. As expected, the level of financial literacy has a negative and significant impact of about 3\%

\footnotetext{
${ }^{9}$ An alternative (and complementary) explanation relates behavioral traits to workers' employment statuses. For example, workers with insecure jobs might be more "impatient" than unemployed individuals. Unfortunately, as discussed below, further data and research are needed to fully disentangle behavioral effects.
} 
on the probability of experiencing financial distress. It is important to note that the effect of financial literacy is added to that resulting from a higher level of education. The level of risk aversion is positive, although not significant, suggesting that individuals less willing to take risks are actually more likely to end up in financial distress. In column $e$, and only for this cross-sectional analysis, we can additionally control for the amount of precautionary savings the family can rely on to cope with unexpected events. Although it is statistically significant, the addition of this variable among the regressors do not alter the previous results.

In column $f$ and $g$, in order to control for the level of job insecurity at "family-level" we replace our regressors of main interest with the number of individuals in the family who have an insecure or an atypical job, or are unemployed at the end of year. Similarly to the analysis based on individual level variables, the number of individuals who have an insecure jobs at family level, has a positive effect on the probability of experiencing financial distress, which is economically and statistically similar to that of having in the family a higher number of unemployed individuals. Likewise to the previous analysis, the impact of atypical workers is not statistically significant.

To better identify the effect of financial literacy on financial distress in relation to the different type of job insecurity, we sequentially introduce among the regressors in equation (1) our indicator of financial literacy in interaction with the variables measuring job insecurity (that is, insecure, atypical, and unemployed).

Since the model is non linear, the coefficients on the interaction terms (i.e. how the effect of one variable changes when another variable changes) do not provide the change in the partial effect of the variables on the conditional mean function and care needs to be used to interpret the results (Ai and Norton (2003), Greene (2010), Karaca-Mandic et al. (2011)). In addition, in some cases, the results of hypothesis tests are an artifact of the functional form and do not necessarily have an economically meaningful content (Greene (2010)). To this end, Table (6) reports the estimated interaction effects, as well as the correct marginal effects for the new model specifications. The results for the main variables are substantially in line with those reported on Table (5). However, when we look more closely at the effect of financial literacy, by looking at the estimated effects of the interaction terms, when can observe - with the caveats 
Table 5: ORDINAL LOGIT 2010: AVERAGE MARGINAL EFFECTS

The dependent variable is a categorical variable which measures the financial difficulties households have in keeping up with payments. It ranges from 1 (very easily) to 6 (with great difficulties). For a detailed description of the variables used in this analysis see Table (4).

\begin{tabular}{|c|c|c|c|c|c|c|c|}
\hline & a & $\mathrm{b}$ & C & $\mathrm{d}$ & $\mathrm{e}$ & $\mathrm{f}$ & $\mathrm{g}$ \\
\hline AGE & $\begin{array}{c}0.9991^{* *} \\
(0.000)\end{array}$ & $\begin{array}{c}0.9990^{* *} \\
(0.000)\end{array}$ & $\begin{array}{c}0.9991^{* *} \\
(0.000)\end{array}$ & $\begin{array}{c}0.9990^{* *} \\
(0.000)\end{array}$ & $\begin{array}{c}0.9990^{* *} \\
(0.000)\end{array}$ & $\begin{array}{c}0.9990^{* *} \\
(0.000)\end{array}$ & $\begin{array}{c}0.9990^{* *} \\
(0.000)\end{array}$ \\
\hline SINGLE & $\begin{array}{l}1.0003 \\
(0.013)\end{array}$ & $\begin{array}{l}1.0021 \\
(0.013)\end{array}$ & $\begin{array}{l}1.0016 \\
(0.013)\end{array}$ & $\begin{array}{l}1.0012 \\
(0.013)\end{array}$ & $\begin{array}{l}1.0000 \\
(0.013)\end{array}$ & $\begin{array}{l}1.0014 \\
(0.013)\end{array}$ & $\begin{array}{l}1.0002 \\
(0.013)\end{array}$ \\
\hline DIVORCED & $\begin{array}{c}1.0532^{* * *} \\
(0.016)\end{array}$ & $\begin{array}{c}1.0547^{* * * *} \\
(0.016)\end{array}$ & $\begin{array}{c}1.0553^{* * *} \\
(0.016)\end{array}$ & $\begin{array}{c}1.0554^{* * *} \\
(0.016)\end{array}$ & $\begin{array}{c}1.0545^{* * *} \\
(0.016)\end{array}$ & $\begin{array}{c}1.0547^{* * *} \\
(0.016)\end{array}$ & $\begin{array}{c}1.0539^{* * * *} \\
(0.016)\end{array}$ \\
\hline WIDOW & $\begin{array}{l}1.0321 \\
(0.030)\end{array}$ & $\begin{array}{l}1.0368 \\
(0.030)\end{array}$ & $\begin{array}{l}1.0370 \\
(0.030)\end{array}$ & $\begin{array}{l}1.0357 \\
(0.030)\end{array}$ & $\begin{array}{l}1.0350 \\
(0.031)\end{array}$ & $\begin{array}{l}1.0351 \\
(0.030)\end{array}$ & $\begin{array}{l}1.0344 \\
(0.031)\end{array}$ \\
\hline SEX & $\begin{array}{l}1.0075 \\
(0.009)\end{array}$ & $\begin{array}{l}1.0013 \\
(0.010)\end{array}$ & $\begin{array}{l}0.9993 \\
(0.010)\end{array}$ & $\begin{array}{l}0.9983 \\
(0.010)\end{array}$ & $\begin{array}{l}0.9982 \\
(0.010)\end{array}$ & $\begin{array}{l}0.9994 \\
(0.009)\end{array}$ & $\begin{array}{l}0.9992 \\
(0.009)\end{array}$ \\
\hline EDUCATION & $\begin{array}{c}0.9647^{* * * *} \\
(0.003)\end{array}$ & $\begin{array}{c}0.9655^{* * * *} \\
(0.003)\end{array}$ & $\begin{array}{c}0.9669^{* * *} \\
(0.003)\end{array}$ & $\begin{array}{c}0.9673^{* * *} \\
(0.003)\end{array}$ & $\begin{array}{c}0.9679^{* * *} \\
(0.003)\end{array}$ & $\begin{array}{c}0.9678^{* * *} \\
(0.003)\end{array}$ & $\begin{array}{c}0.9684^{* * * *} \\
(0.003)\end{array}$ \\
\hline FAMILY SIZE & $\begin{array}{c}1.0318^{* * *} \\
(0.005)\end{array}$ & $\begin{array}{c}1.0321^{* * *} \\
(0.005)\end{array}$ & $\begin{array}{c}1.0319 * * * \\
(0.005)\end{array}$ & $\begin{array}{c}1.0317^{* * *} \\
(0.005)\end{array}$ & $\begin{array}{c}1.0314^{* * *} \\
(0.005)\end{array}$ & $\begin{array}{c}1.0312^{* * *} \\
(0.005)\end{array}$ & $\begin{array}{c}1.0310^{* * *} \\
(0.005)\end{array}$ \\
\hline FAMILY INCOME HOLDERS & $\begin{array}{c}0.9455^{* * *} \\
(0.007)\end{array}$ & $\begin{array}{c}0.9433^{* * * *} \\
(0.007)\end{array}$ & $\begin{array}{c}0.9446^{* * *} \\
(0.007)\end{array}$ & $\begin{array}{c}0.9447^{* * *} \\
(0.007)\end{array}$ & $\begin{array}{c}0.9452^{* * *} \\
(0.007)\end{array}$ & $\begin{array}{c}0.9439^{* * *} \\
(0.007)\end{array}$ & $\begin{array}{c}0.9445^{* * *} \\
(0.007)\end{array}$ \\
\hline HOUSE PROPERTY & $\begin{array}{c}0.9144^{* * *} \\
(0.010)\end{array}$ & $\begin{array}{c}0.9171^{* * *} \\
(0.010)\end{array}$ & $\begin{array}{c}0.9199^{* * *} \\
(0.009)\end{array}$ & $\begin{array}{c}0.9204^{* * *} \\
(0.009)\end{array}$ & $\begin{array}{c}0.9206^{* * *} \\
(0.009)\end{array}$ & $\begin{array}{c}0.9224^{* * *} \\
(0.009)\end{array}$ & $\begin{array}{c}0.9226^{* * * *} \\
(0.009)\end{array}$ \\
\hline DEBTS & $\begin{array}{c}1.0534^{* * *} \\
(0.009)\end{array}$ & $\begin{array}{c}1.0498^{* * * *} \\
(0.009)\end{array}$ & $\begin{array}{c}1.0523^{* * *} \\
(0.009)\end{array}$ & $\begin{array}{c}1.0517^{* * *} \\
(0.009)\end{array}$ & $\begin{array}{c}1.0502^{* * *} \\
(0.009)\end{array}$ & $\begin{array}{c}1.0511^{* * *} \\
(0.009)\end{array}$ & $\begin{array}{c}1.0495^{* * *} \\
(0.009)\end{array}$ \\
\hline $\log$ INCOME & $\begin{array}{c}0.9901^{* *} \\
(0.004)\end{array}$ & $\begin{array}{c}0.9908^{* *} \\
(0.004)\end{array}$ & $\begin{array}{c}0.9904^{* *} \\
(0.004)\end{array}$ & $\begin{array}{c}0.9905^{* *} \\
(0.004)\end{array}$ & $\begin{array}{c}0.9908^{* *} \\
(0.004)\end{array}$ & $\begin{array}{c}0.9880^{* * *} \\
(0.003)\end{array}$ & $\begin{array}{c}0.9883^{* * * *} \\
(0.003)\end{array}$ \\
\hline INSECURE & $\begin{array}{c}1.0667^{* * * *} \\
(0.017)\end{array}$ & $\begin{array}{c}1.0553^{* * * *} \\
(0.016)\end{array}$ & $\begin{array}{c}1.0529^{* * *} \\
(0.016)\end{array}$ & $\begin{array}{c}1.0520^{* * *} \\
(0.016)\end{array}$ & $\begin{array}{c}1.0512^{* * *} \\
(0.016)\end{array}$ & & \\
\hline ATYPICAL & $\begin{array}{l}1.0485 \\
(0.032)\end{array}$ & $\begin{array}{l}0.9943 \\
(0.033)\end{array}$ & $\begin{array}{l}0.9886 \\
(0.032)\end{array}$ & $\begin{array}{l}0.9869 \\
(0.032)\end{array}$ & $\begin{array}{l}0.9871 \\
(0.032)\end{array}$ & & \\
\hline UNEMPLOYED & $\begin{array}{c}1.0894^{* *} \\
(0.044)\end{array}$ & $\begin{array}{c}1.0995^{* *} \\
(0.043)\end{array}$ & $\begin{array}{c}1.0959^{* *} \\
(0.044)\end{array}$ & $\begin{array}{c}1.0956^{* *} \\
(0.044)\end{array}$ & $\begin{array}{c}1.0974^{* *} \\
(0.043)\end{array}$ & & \\
\hline SELF EMPLOYED & $\begin{array}{c}0.9614^{* * *} \\
(0.012)\end{array}$ & $\begin{array}{c}0.9191^{* * *} \\
(0.019)\end{array}$ & $\begin{array}{c}0.9213^{* * *} \\
(0.019)\end{array}$ & $\begin{array}{c}0.9213^{* * *} \\
(0.019)\end{array}$ & $\begin{array}{c}0.9244^{* * *} \\
(0.019)\end{array}$ & $\begin{array}{c}0.9239^{* * *} \\
(0.018)\end{array}$ & $\begin{array}{c}0.9269^{* * *} \\
(0.018)\end{array}$ \\
\hline BANK ACCOUNT SAVINGS & $\begin{array}{c}0.8919^{* * *} \\
(0.017)\end{array}$ & $\begin{array}{c}0.8934^{* * * *} \\
(0.016)\end{array}$ & $\begin{array}{c}0.8971^{* * *} \\
(0.017)\end{array}$ & $\begin{array}{c}0.8978^{* * *} \\
(0.017)\end{array}$ & $\begin{array}{c}0.8986^{* * *} \\
(0.017)\end{array}$ & $\begin{array}{c}0.8971^{* * *} \\
(0.017)\end{array}$ & $\begin{array}{c}0.8978^{* * *} \\
(0.017)\end{array}$ \\
\hline FIN CONSTRAINED & $\begin{array}{c}1.1488^{* * * *} \\
(0.036)\end{array}$ & $\begin{array}{c}1.1537^{* * * *} \\
(0.037)\end{array}$ & $\begin{array}{c}1.1527^{* * *} \\
(0.038)\end{array}$ & $\begin{array}{c}1.1513^{* * *} \\
(0.038)\end{array}$ & $\begin{array}{c}1.1483^{* * *} \\
(0.038)\end{array}$ & $\begin{array}{c}1.1490^{* * *} \\
(0.036)\end{array}$ & $\begin{array}{c}1.1461^{* * *} \\
(0.036)\end{array}$ \\
\hline PART TIME & & $\begin{array}{c}1.0505^{* * * *} \\
(0.018)\end{array}$ & $\begin{array}{c}1.0510^{* * * *} \\
(0.018)\end{array}$ & $\begin{array}{c}1.0511^{* * *} \\
(0.018)\end{array}$ & $\begin{array}{c}1.0503^{* * *} \\
(0.018)\end{array}$ & $\begin{array}{c}1.0450^{* * *} \\
(0.016)\end{array}$ & $\begin{array}{c}1.0444^{* * * *} \\
(0.016)\end{array}$ \\
\hline NUMBER JOB EXPERIENCE & & $\begin{array}{c}1.0057^{* *} \\
(0.002)\end{array}$ & $\begin{array}{c}1.0065^{* * *} \\
(0.002)\end{array}$ & $\begin{array}{c}1.0063^{* * *} \\
(0.002)\end{array}$ & $\begin{array}{c}1.0062^{* *} \\
(0.002)\end{array}$ & $\begin{array}{c}1.0063^{* * *} \\
(0.002)\end{array}$ & $\begin{array}{c}1.0062^{* * * *} \\
(0.002)\end{array}$ \\
\hline MIN MAX LITERACY & & & $\begin{array}{c}0.9694^{* * *} \\
(0.009)\end{array}$ & $\begin{array}{c}0.9686^{* * *} \\
(0.009)\end{array}$ & $\begin{array}{c}0.9722^{* * *} \\
(0.009)\end{array}$ & $\begin{array}{c}0.9693^{* * *} \\
(0.009)\end{array}$ & $\begin{array}{c}0.9728^{* * * *} \\
(0.009)\end{array}$ \\
\hline RISK AVERSION & & & & $\begin{array}{l}1.0072 \\
(0.005)\end{array}$ & $\begin{array}{l}1.0055 \\
(0.005)\end{array}$ & $\begin{array}{l}1.0071 \\
(0.005)\end{array}$ & $\begin{array}{l}1.0055 \\
(0.005)\end{array}$ \\
\hline PRECAUTIONARY & & & & & $\begin{array}{c}1.0000^{* * * *} \\
(0.000)\end{array}$ & & $\begin{array}{c}1.0000^{* * * *} \\
(0.000)\end{array}$ \\
\hline INSECURE FAMILY & & & & & & $\begin{array}{c}1.0468^{* * *} \\
(0.011)\end{array}$ & $\begin{array}{c}1.0457^{* * * *} \\
(0.011)\end{array}$ \\
\hline ATYPICAL FAMILY & & & & & & $\begin{array}{l}1.0062 \\
(0.021)\end{array}$ & $\begin{array}{l}1.0058 \\
(0.021)\end{array}$ \\
\hline UNEMPLOYED FAMILY & & & & & & $\begin{array}{c}1.0495^{* *} \\
(0.026)\end{array}$ & $\begin{array}{c}1.0506^{* *} \\
(0.026)\end{array}$ \\
\hline $\mathrm{N}$ & 3492 & 3492 & 3492 & 3492 & 3492 & 3492 & 3492 \\
\hline
\end{tabular}

${ }^{*} \mathrm{p}<0.10,{ }^{* *} \mathrm{p}<0.05,{ }^{* * *} \mathrm{p}<0.01$

Standard errors are in parentheses. 
highlighted above - that for atypical workers a greater level of financial literacy can reduce the probability of experiencing financial distress. Since these workers are a kind of atypical self-employed workers, in general with higher level of education and job quality, ${ }^{10}$ it seems reasonable that atypical workers with a higher level of financial literacy can better handle their financial situation. Interesting to note, the difference between insecure and atypical in columns $b$ and $c$ is also statistically significant at $10 \%$.

\subsection{Panel data: Ordinal logit}

The results of the analysis that relies on Baetschmann et al. (2011)'s estimator are reported in Table (7). By and large, these results are consistent with the cross-sectional analysis. However, we cannot rely on these estimations to make strong claims on our main variables of interest. As expected in such a short panel, the variables accounting for financial literacy are not significant, because like education, they are slowly changing variables and thus difficult to estimate together. In addition, we only have a limited number of heads of households in our panel dataset that change employment statuses.

For the remainder of this section, we shall thus estimate a random ordinal logit model with clustered errors (Rabe-Hesketh and Skrondal (2008)). However, to explicitly allow unobservable personality traits to be correlated with regressors, we included the group-mean of job characteristics and income as additional predictors in some specifications. This allow us to remove the potential bias in the random effect models, and also to test for correlations between the group-effect and the regressors (Gelman and Hill (2007)).

The estimated odds ratios are presented in Table (7). Although the economic impact is now larger, the results are in line with the cross-sectional ordinal-logit analysis. In particular, a parttime activity as well as a greater number of insecure activities are associated with higher levels of financial difficulties, whereas financial access tends to reduce difficulties (see columns $a$ and b). Also consistent with the cross-sectional analysis, low levels of financial literacy will increase the probability of experiencing financial troubles (see column $b$ ). In column $c$ we include the group-mean variables as additional regressors. Because coefficients on the mean regressors (not reported), which can be interpreted as a test for individual fixed effects, are almost all

\footnotetext{
${ }^{10}$ In our sample the correlation between education and atypical workers is equal to 0.05 , whereas it is equal to -0.07 for insecure workers.
} 
Table 6: ORDINAL LOGIT 2010: AVERAGE MARGINAL EFFECTS FOR THE MODEL WITH INTERACTIONS TERMS The dependent variable is a categorical variable which measures the financial difficulties households have in keeping up with payments. It ranges from 1 (very easily) to 6 (with great difficulties). For a detailed description of the variables used in this analysis see Table (4).

\begin{tabular}{|c|c|c|c|}
\hline & $a$ & $b$ & c \\
\hline \multirow[t]{2}{*}{ AGE } & $0.9990^{* *}$ & $0.9990^{* *}$ & $0.9990^{* *}$ \\
\hline & $(0.000)$ & $(0.000)$ & $(0.000)$ \\
\hline \multirow[t]{2}{*}{ SINGLE } & 1.0002 & 1.0005 & 1.0007 \\
\hline & $(0.013)$ & $(0.013)$ & $(0.013)$ \\
\hline \multirow[t]{2}{*}{ DIVORCED } & $1.0544^{* * *}$ & $1.0550^{* * *}$ & $1.0553^{* * *}$ \\
\hline & $(0.016)$ & $(0.016)$ & $(0.016)$ \\
\hline \multirow[t]{2}{*}{ WIDOW } & 1.0353 & 1.0356 & 1.0351 \\
\hline & $(0.031)$ & $(0.031)$ & $(0.031)$ \\
\hline \multirow[t]{2}{*}{ SEX } & 0.9979 & 0.9976 & 0.9981 \\
\hline & $(0.010)$ & $(0.010)$ & $(0.010)$ \\
\hline \multirow[t]{2}{*}{ EDUCATION } & $0.9679^{* * *}$ & $0.9679^{* * *}$ & $0.9677^{* * *}$ \\
\hline & $(0.003)$ & $(0.003)$ & $(0.003)$ \\
\hline \multirow[t]{2}{*}{ FAMILY SIZE } & $1.0314^{* * *}$ & $1.0315^{* * *}$ & $1.0316^{* * *}$ \\
\hline & $(0.005)$ & $(0.005)$ & $(0.005)$ \\
\hline \multirow[t]{2}{*}{ FAMILY INCOME HOLDERS } & $0.9453^{* * *}$ & $0.9454^{* * *}$ & $0.9454^{* * *}$ \\
\hline & $(0.007)$ & $(0.007)$ & $(0.007)$ \\
\hline \multirow[t]{2}{*}{ HOUSE PROPERTY } & $0.9205^{* * *}$ & $0.9206^{* * *}$ & $0.9203^{* * *}$ \\
\hline & $(0.009)$ & $(0.009)$ & $(0.009)$ \\
\hline \multirow[t]{2}{*}{ DEBTS } & $1.0502^{* * *}$ & $1.0498^{* * *}$ & $1.0501^{* * *}$ \\
\hline & $(0.009)$ & $(0.009)$ & $(0.009)$ \\
\hline \multirow[t]{2}{*}{$\log$ INCOME } & $0.9908^{* *}$ & $0.9908^{* *}$ & $0.9910^{* *}$ \\
\hline & $(0.004)$ & $(0.004)$ & $(0.004)$ \\
\hline \multirow[t]{2}{*}{ INSECURE } & $1.0582^{* * *}$ & $1.0584^{* * *}$ & $1.0583^{* * *}$ \\
\hline & $(0.021)$ & $(0.021)$ & $(0.021)$ \\
\hline \multirow[t]{2}{*}{ ATYPICAL } & 0.9868 & 0.9918 & 0.9916 \\
\hline & $(0.032)$ & $(0.027)$ & $(0.027)$ \\
\hline \multirow[t]{2}{*}{ UNEMPLOYED } & $1.0971^{* *}$ & $1.0974^{* *}$ & $1.1291^{* *}$ \\
\hline & $(0.044)$ & $(0.043)$ & $(0.065)$ \\
\hline \multirow[t]{2}{*}{ MIN MAX LITERACY } & $0.9730^{* * *}$ & $0.9728^{* * *}$ & $0.9767^{* *}$ \\
\hline & $(0.009)$ & $(0.009)$ & $(0.009)$ \\
\hline \multirow[t]{2}{*}{ SELF EMPLOYED } & $0.9245^{* * *}$ & $0.9241^{* * *}$ & $0.9246^{* * *}$ \\
\hline & $(0.019)$ & $(0.019)$ & $(0.019)$ \\
\hline \multirow[t]{2}{*}{ PART TIME } & $1.0502^{* * *}$ & $1.0504^{* * *}$ & $1.0503^{* * *}$ \\
\hline & $(0.018)$ & $(0.018)$ & $(0.017)$ \\
\hline \multirow[t]{2}{*}{ NUMBER JOB EXPERIENCE } & $1.0063^{* *}$ & $1.0061^{* *}$ & $1.0061^{* *}$ \\
\hline & $(0.002)$ & $(0.002)$ & $(0.002)$ \\
\hline \multirow[t]{2}{*}{ BANK ACCOUNT SAVINGS } & $0.8986^{* * *}$ & $0.8987^{* * *}$ & $0.8984^{* * *}$ \\
\hline & $(0.017)$ & $(0.017)$ & $(0.017)$ \\
\hline \multirow[t]{2}{*}{ FIN CONSTRAINED } & $1.1480^{* * *}$ & $1.1483^{* * *}$ & $1.1489^{* * *}$ \\
\hline & $(0.038)$ & $(0.038)$ & $(0.038)$ \\
\hline \multirow[t]{2}{*}{ RISK AVERSION } & 1.0055 & 1.0053 & 1.0054 \\
\hline & $(0.005)$ & $(0.005)$ & $(0.005)$ \\
\hline PRECAUTIONARY & $1.0000^{* * *}$ & $1.0000^{* * *}$ & $1.0000^{* * *}$ \\
\hline & $(0.000)$ & $(0.000)$ & $(0.000)$ \\
\hline Interaction Terms & & & \\
\hline INSECURE* MIN MAX LITERACY & 1.011 & 1.009 & 1.012 \\
\hline & $(0.032)$ & $(0.033)$ & $(0.033)$ \\
\hline ATYPICAL* MIN MAX LITERACY & & $0.922^{*}$ & $0.927^{*}$ \\
\hline & & $(0.042)$ & $(0.042)$ \\
\hline UNEMPLOYED* MIN MAX LITERACY & & & 1.060 \\
\hline & & & $(0.059)$ \\
\hline $\mathrm{N}$ & 3492 & 3492 & 3492 \\
\hline
\end{tabular}

${ }^{*} \mathrm{p}<0.10,{ }^{* *} \mathrm{p}<0.05,{ }^{* * *} \mathrm{p}<0.01$

Standard errors in parentheses. 
insignificant, there is not great residual correlation to be accounted for within our main regressors. However, two exceptions warrant closer attention: the coefficients on the number of job experiences and on the level of income.

A similar conclusion is reached when examining the specification which includes familylevel variables. In line with the cross-sectional analysis, the higher the number of family members with insecure jobs, the higher the probability of being in greater financial distress. This effect is statistically and economically similar to the effect arising from a higher number of unemployed family members. Since the interpretations of interactions in non-linear panel model is not straightforward and involved the same problems highlighted above, we refrain from replicating for the panel dataset the specification with the interaction terms.

\section{ROBUSTNESS CHECKS}

Model specification. The ordered logit model makes an important 'parallel odds' assumption. It assumes that only the cut-off parameters are different across financial statutes, whereas the slope coefficients of the link function for the parameters of interest remain identical. In the context of our study, this means that individual characteristics are assumed to have an equiproportionate effect on the probabilities of either increases or decreases in financial distress. To formally test the proportional odds assumption, we use the Wald test and find that our (cross-sectional) model do violate this assumption for a restrict number of variables. Specifically, the variables which do not pass the test were those related to being unemployed and insecure workers, to the level of income, and to having a bank account. We thus fit a model that is less restrictive than the ordinal logit model but more parsimonious and interpretable than those fitted by a non-ordinal method, such as multinomial logistic regression. ${ }^{11}$ The differences are largely a matter of degree although a bit more difficult to interpret. In particular, insecure and unemployed workers tend to follow the same path. However, unemployed heads of households tend more likely to be in more extreme categories, i.e. they are more likely to report lower level of financial distress but they are also more likely to report higher level of financial distress

\footnotetext{
${ }^{11}$ In Stata this corresponds to the ogologit2 command developed by Williams (2006).
} 
Table 7: PANEL DATA ANALYSIS ORDINAL LOGIT

The dependent variable is a categorical variable which measures the financial difficulties households have in keeping up with payments. It ranges from 1 (very easily) to 6 (with great difficulties). For a detailed description of the variables used in this analysis see Table (4).

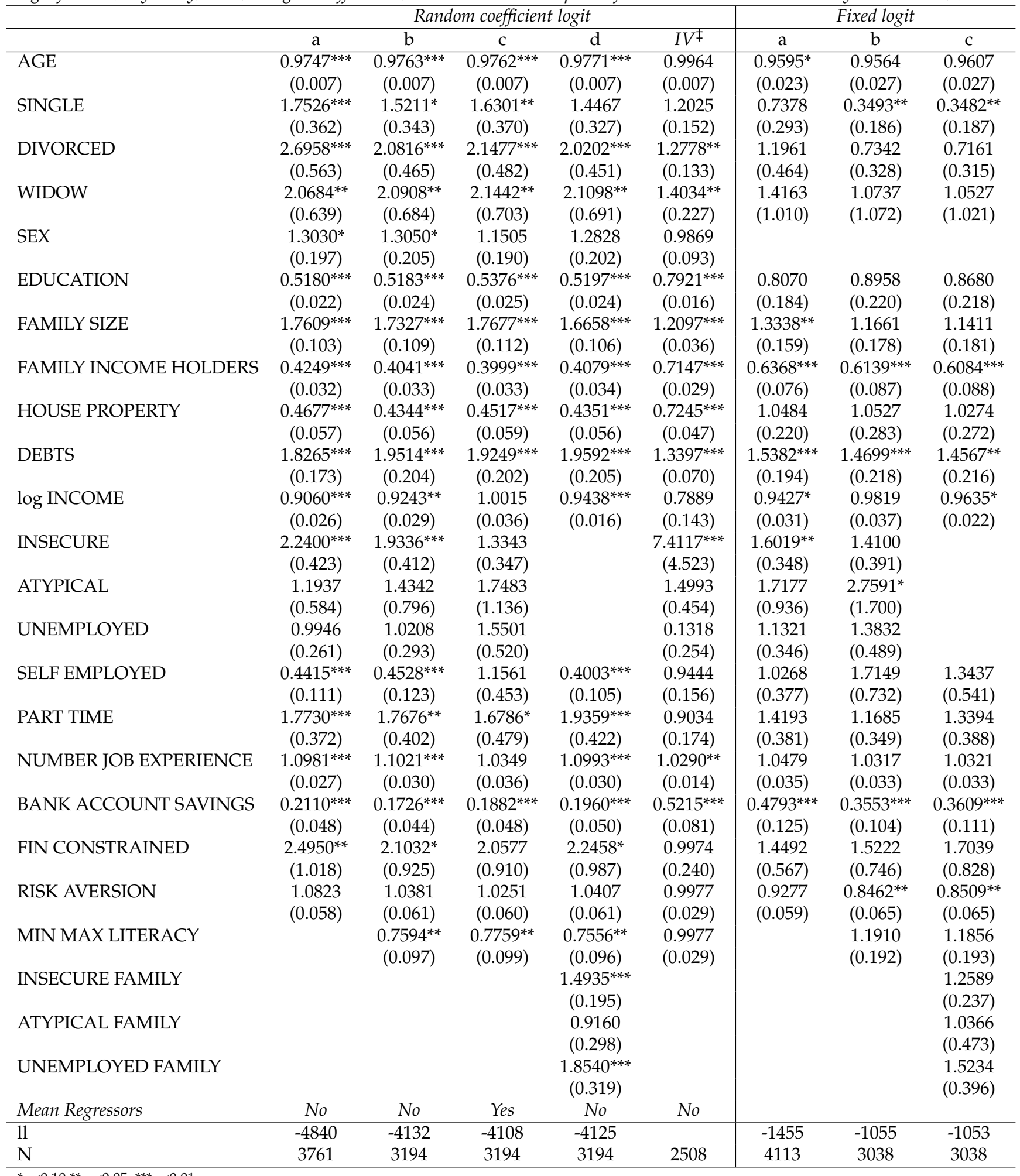

${ }^{*} \mathrm{p}<0.10,{ }^{* *} \mathrm{p}<0.05,{ }^{* * *} \mathrm{p}<0.01$

$\ddagger$ Linear two-stage least-squares for panel data.The instrumented variable are INSECURE and UNEMPLOYED. The instruments are TRADE - UNION MEMBERS 1997 LABOURCONFLICTS 1997 , INSECURE $E_{t-1}$, UNEMPLOYED $_{t-1}$ and regional dummies. The test for overdintifying restrictions is equal to 0.139 . Standard errors are in parentheses. 
than insecure workers. Within this framework it also appears crucial to have a bank account to reduce the probability of experiencing higher level of financial distress, whereas the effect of higher level of income can at some point reverse (i.e. with higher level of income increasing the probability of experiencing higher level of financial distress).

Endogeneity problem. One of the main concern is that the main variables of interest (i.e. insecure and unemployed) might be endogenous because of the potential correlation with idiosyncratic component of the error term that also generates an increase in the probability of financial distress. To address this issue, we must identify determinants of job insecurity and unemployement that are not correlated with the error term in equation (1). We thus rely on the number of workers enrolled in the main Italian trade union as well as the number of labour conflicts for contract renewal as our instrumental variables in 1997, the year in which a fundamental re-organization of the labour market has taken place (see footnote 1). The main idea is that the higher the strength of the trade union was in 1997 within each region, the lower the level of job insecurity is in the years of our investigation. It is also important to stress that the forces behind the change in the Italian labour market where substantially different from the forces that driven the development of the financial system in the first half of the 1980s (see Guiso et al. 2004).

First, we follow Rivers and Vuong 1988' procedure to test for endogeneity. We first regress the dummy for insecure and unemployed workers on our exogenous variables, regional and wave dummies, and the trade-union instruments (also interacted with the wave dummies). We then add the residual of this equation to the equation for financial distress. The $t$-statistic on its coefficient is a test of endogeneity. The analysis (not reported) evidences a $t$-statistic equal to -4.03 for insecure, suggesting the endogeneity of our variable for insecure workers, and equal to 1.28 for unemployed, suggesting there is no endogeneity problem for this variable. The first-stage regression also highlighted a negative and statistically significant relationship between the dummy for insecure workers and the unionized workers and labour conflicts in 1997, whereas a milder relationship exists for unemployed workers (suggesting that our instruments are weaker for this variable).

We therefore compute a two-stage least-squares generalization for panel data of the IV method 
instrumenting for the insecure and unemployed dummies, relying on the trade-union members and number of conflicts as our instrumental variables (also in interactions with wave dummies), lagged values of unmployed and insecure, along with regional dummies. Results confirm and reinforce our previous analysis, suggesting that insecure workers are more likely to experience financial distress (see column IV in (7)). The results are statistically significant and tests of overidentifying restrictions confirms that our instruments are valid. We refrain, however, from economically intepreting these coefficients. The size of these coefficients is actually "too high" probably due to the small time-variation in these variables in such a short panel and instruments are weak for unemployed. On the other hand, we remain coinfident on the general interpretation of our analysis as these results are qualitatively consistent with the cross-sectional analysis.

Behavioural Characteristiscs. We also constructed proxies to account for behavioral characteristics; our results were in line with previous work. In particular, as in McCarthy (2011) and Anderloni et al. (2012), impatience individuals are more likely to experience financial distress, whereas organized individuals are less likely to experience such distress. ${ }^{12}$ In addition, the introduction of these variables reduced the impact of financial literacy. However, the stability of behavioural traits over the lifecycle (and employment statuses) is still a controversial strand of the research in psychology (see, for example, Borghans et al. (2008)). ${ }^{13}$ Thus, in order to have clear indications about the role of behavioral traits on financial distress, further research is needed.

\footnotetext{
${ }^{12}$ In particular, we proxy "live for today", "organized", and "impatience" by means of the following questions in our analyses of robustness:

- How often do you check the balance in your current account? at least once a week I at least once a fortnight I less than once a month I never I don't know

- Which of the following options best describes your actions when you receive your bank statement? I check my receipts against the statement I I check that the amounts credited and debited in the statement are reasonable I I just check the balance I I don't read it I I don't receive a statement I don't know

- Imagine that you find yourself in the following situation You have won the lottery and will receive a sum equal to your household's net yearly revenue. You will receive the money in a year's time. However, if you give up part of the sum you can collect the rest of your win immediately. To obtain the money immediately would you give up $20 \%$ of your win? Yes I No What about $10 \%$ ? Yes I No And $5 \%$ ? Yes I No Just $2 \%$ ? Yes I No

${ }^{13}$ In this regard, there are two strands of research: the social-cognitive theorists and the trait theorists. The first group of theorists feature investments and social interactions as direct determinants of traits that are assumed to evolve as a function of the experiences of agents, whereas the latter group of theorists do not consider this possibility. Instead they emphasize self-learning about traits that evolve by fixed biological principles unrelated to the experiences of individuals (Almlund et al. (2011)).
} 


\section{CONCLUSIONS}

In this paper we investigated the relationship between different job categories and financial distress, taking into account financial access and literacy. We found that heads of households with insecure jobs are more likely to experience financial distress. This probability is higher if insecure workers are employed on a part-time basis. This result also appears robust in a setting that control for family (job) characteristics and in our panel specification, which further controls for unobserved head of household's characteristics and endogeneity problem. Since in our dataset insecure workers are more likely to look for credit and hold debts in order to purchase goods, these results seem to identify insecure workers' attempts to be "consumers"

- despite the uncertainty in their income - as a possible driver of financial distress. However, higher levels of financial literacy counterbalance the observed negative effects of job insecurity by reducing the probability of higher levels of financial distress, especially for atypical workers. Further research is needed to fully complete the picture suggested by these results, particularly in the areas of the stability of behavioral parameters over time and employment status. 


\section{References}

Ai, C., Norton, E., 2003. Interaction terms in logit and probit models. Economics letters 80 (1), 123-129.

Almlund, M., Duckworth, A., Heckman, J., Kautz, T., 2011. Personality psychology and economics. Tech. rep., National Bureau of Economic Research.

Anderloni, L., Bacchiocchi, E., Vandone, D., 2012. Household financial vulnerability: An empirical analysis. Research in Economics 66 (3), 284 - 296.

Baetschmann, G., Staub, K., Winkelmann, R., Jan. 2011. Consistent estimation of the fixed effects ordered logit model. IZA Discussion Papers 5443, Institute for the Study of Labor (IZA).

Bank of Italy, 2008. Annual report. Tech. rep.

Benito, A., 2006. Does job insecurity affect household consumption? Oxford Economic Papers $58(1), 157-181$.

Bertola, G., Koeniger, W., 2007. Consumption smoothing and income redistribution. European Economic Review 51 (8), 1941-1958.

Betti, G., Dourmashkin, N., Rossi, M., Yin, Y., 2007. Consumer over-indebtedness in the EU: measurement and characteristics. Journal of Economic Studies 34 (2), 136-156.

Bonin, H., Dohmen, T., Falk, A., Huffman, D., Sunde, U., 2007. Cross-sectional earnings risk and occupational sorting: The role of risk attitudes. Tech. rep.

Borghans, L., Duckworth, A., Heckman, J., Ter Weel, B., 2008. The economics and psychology of personality traits. Tech. rep., National Bureau of Economic Research.

Brown, S., Taylor, K., 2008. Household debt and financial assets: evidence from Germany, Great Britain and the USA. Journal of the Royal Statistical Society: Series A (Statistics in Society) $171(3), 615-643$.

Browning, M., Crossley, T. F., 2009. Shocks, stocks, and socks: Smoothing consumption over a temporary income loss. Journal of the European Economic Association 7 (6), 1169-1192.

Cappellari, L., Leonardi, M., 2013. Earnings instability and tenure. Tech. rep.

Chamberlain, G., January 1980. Analysis of covariance with qualitative data. Review of Economic Studies 47 (1), 225-38.

Cramer, J. S., Hartog, J., Jonker, N., Van Praag, C. M., 2002. Low risk aversion encourages the choice for entrepreneurship: an empirical test of a truism. Journal of Economic Behavior \& Organization 48 (1), 29-36. 
Dohmen, T., Falk, A., Huffman, D., Sunde, U., Schupp, J., Wagner, G. G., 2011. Individual risk attitudes: measurement, determinants, and behavioural consequences. Journal of the European Economic Association 9 (3), 522-550.

Faiella, I., Apr. 2008. Accounting for sampling design in the SHIW. Temi di discussione 662, Bank of Italy, Economic Research Department.

Fricke, C., Österreich, D., Schulze, E., Wagner, G. G., 2007. Überschuldung ist ein problem fehlender netzwerke. DIW Wochenbericht 74 (7), 95-100.

Gatti, D., Rault, C., Vaubourg, A.-G., 2012. Unemployment and finance: how do financial and labour market factors interact? Oxford Economic Papers 64 (3), 464-489.

Gelman, A., Hill, J., 2007. Data Analysis Using Regression and Multilevel/Hierarchical Models. Cambridge University Press.

Giannetti, M., 2011. Liquidity constraints and occupational choice. Finance Research Letters $8(1), 37-44$.

Greene, W., 2010. Testing hypotheses about interaction terms in nonlinear models. Economics Letters 107 (2), 291-296.

Guiso, L., Sapienza, P., Zingales, L., 2004. Does local financial development matter? The Quarterly Journal of Economics 119 (3), 929-969.

Jappelli, T., Pistaferri, L., Sep. 2009. The consumption response to income changes. CSEF Working Papers 237, Centre for Studies in Economics and Finance (CSEF), University of Naples, Italy.

Jappelli, T., Pistaferri, L., 2010. Does consumption inequality track income inequality in Italy? Review of Economic Dynamics 13 (1), 133-153.

Karaca-Mandic, P., Norton, E., Dowd, B., 2011. Interaction terms in nonlinear models. Health Services Research 47 (1pt1), 255-274.

Lusardi, A., Mitchell, O. S., 2007. Baby boomer retirement security: The roles of planning, financial literacy, and housing wealth. Journal of Monetary Economics 54 (1), 205-224.

Lusardi, A., Tufano, P., Mar. 2009. Debt literacy, financial experiences, and overindebtedness. NBER Working Papers 14808, National Bureau of Economic Research, Inc.

Magri, S., 2007. Credit market imperfections, social mobility and income risk: the evolution of the Italian households' debt.

McCarthy, Y., Mar. 2011. Behavioural characteristics and financial distress. Research Technical Papers 6, Central Bank of Ireland. 
Messenger, J. C., 2010. Working time trends and developments in Europe. Cambridge Journal of Economics.

Molenberghs, G., Verbeke, G., 2000. Linear mixed models for longitudinal data. Springer, New York.

OECD, 1994a. Jobs study, evidence and explanations. part I: Labour market trends and underlying forces of change.

Pagano, M., Volpin, P., 2008. Labor and finance. Paper prepared for the conference on labor, law, politics and finance, Institute for the Study of Labor (IZA).

Picchio, M., 2006. Wage differentials and temporary jobs in Italy. Discussion Papers (Departement des Sciences Economiques) 33, Universite catholique de Louvain, Departement des Sciences Economiques.

Rabe-Hesketh, S., Skrondal, A., 2008. Multilevel and longitudinal modeling using Stata (Second Edition). Stata Press.

Rivers, D., Vuong, Q. H., 1988. Limited information estimators and exogeneity tests for simultaneous probit models. Journal of Econometrics 39 (3), 347-366.

Sala, H., Silva, J. I., Toledo, M., 2012. Flexibility at the margin and labor market volatility in OECD countries. The Scandinavian Journal of Economics 114 (3), 991-1017.

Walker, C. M., 1996. Financial management, coping and debt in households under financial strain. Journal of Economic Psychology 17 (6), 789 - 807.

Williams, R., 2006. Generalized ordered logit/partial proportional odds models for ordinal dependent variables. Stata Journal 6 (1), 58-82(25).

Worthington, A., 2005. Debt as a source of financial stress in Australian households. International Journal of Consumer Studies 30 (1), 2-15. 


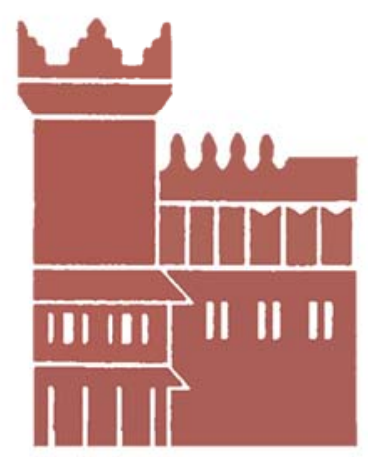

Alma Mater Studiorum - Università di Bologna DEPARTMENT OF ECONOMICS

Strada Maggiore 45

40125 Bologna - Italy

Tel. +39051 2092604

Fax +390512092664

http://www.dse.unibo.it 